\title{
The Role of Contemporary Actuarial Communication in Determining The Insurance Risks of the State of Australia (Melbourne)
}

\author{
Ms. ASEEL KHALED YOUSEF MAQABLEH \\ JORDAN - AMMAN
}

\begin{abstract}
The researcher investigated the insurance sector in Australia after identifying the most important foundations on which actuarial studies in Australia are based in order to arrive at the role of actuarial communication, which aims at coordination and joint cooperation in order to examine the financial situation of the insurance sector in comparison to other countries, and the role of actuarial communication .The researcher's dilemma stemmed from financial indications of organizations that engage in insurance or reinsurance activities, which can be used to detect the type of risk, but not the quantity of risk or the time of occurrence. As a result, the researcher devised assumptions for this study, the most crucial of which is that "there are no statistically significant disparities between contemporary actuarial communication and insurance risks. "The researcher came to several conclusions in this study, the most notable of which was that premiums issued in Australia are increasing over time, indicating a high level of risk. The researcher concluded the study with several recommendations, the most prominent of which was that local Australian companies should establish an actuarial studies department in order to broaden the scope of insurance activities without resorting to high-cost external studies or hiring insurance experts to assess the adequacy of financial coverage when starting a new insurance activity.
\end{abstract}

Keywords: Contemporary Actuarial, the insurance Risks.

DOI: $10.7176 / \mathrm{JEP} / 12-31-02$

Publication date: November $30^{\text {th }} 2021$

\section{INTRODUCTION}

Actuaries in the insurance sector play an important role in calculating and determining the expected risks to which the insurance company is exposed, and based on previous data and experiences they have, they set adequate and fair technical prices and the appropriate premium to meet the expected compensation at the end of the year, with appropriate technical provisions to meet these obligations as well as financial reserves to maintain On the financial solvency of the institution and its ability to meet it. Actuaries complement the role of risk managers in their expected calculation, while risk management is concerned with calculating and identifying unexpected risks such as global financial crises, political and security turmoil, and ensuring that investment risks are managed appropriately and others facing the company.One of the most important problems faced by Australia in general and especially Melbourne is the risks that threaten private insurance companies. Therefore, the current research seeks to know the role of actuarial science in managing these risks, anticipating them, and seeking to solve them.

\section{THE IMPORTANCE OF STUDYING:}

The importance of study centers in identifying actuarial studies in the modern era and the importance of these studies in reducing insurance risks, especially in Omani insurance companies. Where the insurance sector witnessed a clear impact due to the global financial crisis that worked to change the insurance policy until it came to changing the monetary policy of the banks, which led to the failure of the major insurance companies globally, and this was reflected on the medium and small insurance companies. The importance of this study also stems from the importance of the Omani insurance sector and its supportive role in increasing the national economy and attracting the workforce. Therefore, this sector is characterized by remarkable activity and its impact on external variables, especially the financial activities related to reinsurance companies.

The importance of this study also comes from the importance of the risks that insurance companies are exposed to, as insurance companies in the Sultanate of Oman may be exposed to the risks of non-payment, which leads the company to financial default, which is likely to lead it to declare its bankruptcy due to its inability to deal with this default. Its insurance activities are generally affected.

Hence, the role of contemporary actuarial communication is achieved in determining the insurance risks to which companies are exposed and how to prevent and limit them. In order for the insurance sector to practice its activity away from the financial risks that are likely to expose many insurance companies to risks, and this leads the insurance sector to financial failure. 


\section{OBJECTIVES OF THE STUDY:}

Given the multiplicity of insurance companies and the practice of their various activities in the insurance sector, this study came to identify the role of contemporary actuarial communication for these companies, and to indicate the risks that the insurance sector may be exposed to. The study also came to know the reality of the insurance sector and what are the risks. What you may be exposed to and how to reduce it.

\section{THIS STUDY AIMS TO FIND OUT THE FOLLOWING:}

1. Identifying actuarial studies and the reality of their application. Explanation of the role of actuarial communication in reducing the severity of risks for the insurance sector.

2. Identifying the extent to which the periodic actuarial study Knowing the extent of dependence on foreign investments in reducing the risk of risks in the insurance sector.

3. Explanation of the adequacy of contemporary actuarial communication in increasing the activities of the insurance sector Australia countries.

4. Identifying the extent of the relationship between contemporary actuarial communications and the profits of insurance companies.

\section{HYPOTHESES ARE BEING INVESTIGATED:}

The fundamental premise is that actuarial communication and modern insurance have no statistically significant differences.

The following sub-hypotheses are included in the main hypothesis:

Insurance, insurance, insurance. Second, written premiums and insurance risks have a statistically significant link. Finally, there is no statistically significant link between anticipated compensation and insurance risks. Fourth, commissions, manufacturing costs, and insurance risks have a statistically significant link. Fifth, no statistically significant link exists between general and administrative costs and insurance risks.

\section{THE FOLLOWING SOURCES WERE USED IN THIS STUDY:}

Theoretical approach: defining the theoretical framework and identifying the most important published studies on the subject by reading international books, research and articles related to the subject of the study.

\section{SUMMARY OF PROPOSAL:}

The financial crisis has had a dramatic effect on the insurance industry. The impact of the crisis caused various insurance firms to fail to fulfil financial requirements. This has led to the formulation of the research question, whether enterprise risk management (ERM) could have alleviated the financial crisis. A study has examined the impact of ERM on Dutch insurance companies' performance, both before and during the financial crisis. Results show that firms with a higher ERM implementation level have a lower ROA than those with a lower ERM level in the pre-crisis period.

\section{RESEARCH QUESTION:}

The following research question can be formulated using the problem statement: Is ERM deployment reducing the impact of the crisis on insurance company performance?

The sub-questions:

What exactly is a risk?

What is the best way to handle risk?

What advantages does enterprise risk management provider, and how does it vary from traditional risk management?

\section{LITERATURE REVIEW:}

Several areas of risk management and performance are explored in this literature study. The definition of risk will be followed by a review of two risk management methodologies, traditional risk management, and enterprise risk management, as well as the differences between them. The emphasis will be on ERM and the advantages of doing so. Following that, the Solvency Directive, one of the most important European rules for insurance businesses, is discussed. The hypotheses will bring the chapter to a close.

\section{PROBLEM:}

Insurance companies were less affected than banks (Eling\&Schmeiser, 2010). This is because of the difference in business models. Insurance companies are funded in advance and the payments are linked to claims. Many insurers have not been directly affected by the credit crunch that was at the root of the financial crisis. 


\section{WHAT IS THE RISK?}

According to Horcher (2005), risk and exposure are inextricably related and often used terms. Interchangeable. The chance of loss is defined as risk, whereas the possibility of loss is defined as exposure. As a result of exposure, there is a risk. Financial market exposure can result in losses, but it can also result in gains or profits. Risk refers to the possibility of losing money as a result of market exposure and developments. Because any organization exists to deliver value to its stakeholders, it requires a certain level of exposure to generate profit and benefit. There are two forms of risk that insurance businesses face: financial risk and non-financial risk (Ai \& Brockett, 2008). Financial hazards have become more relevant in recent years. As the corporate environment changes, new forms of hazards emerge (Casualty Actuarial Society [CAS], 2003). Companies, for example, are exposed to foreign exchange risk as a result of increased globalization. The terms "financial risk" and "financial market risk" relate to the hazards associated with capital and financial markets (Ai \& Brockett, 2008). Interest rate risk, commodity risk, and foreign exchange risk are all examples of market risk (McNeil, Frey, $\&$ Embrocates, 2005). The credit risk, or default risk, is defined as the risk of not obtaining promised repayments on outstanding investments due to the borrower's default (McNeil et al., 2005). (Ai \& Brockett, 2008).Hazard risk, operational risk, and strategic risk are all examples of non-financial hazards (Ai \& Brockett, 2008). Physical risks include theft, fire, liability claims, business interruptions, and so on. The Basel Committee on Banking Supervision (2004) defines operational risk as "the risk of loss coming from inadequate or failing internal processes, people, and systems, or external events." Internal and external fraud, products and business practices, physical asset damage, business disruption and system failures, and execution, delivery, and process management are all examples of this. The firm's entire strategies are inextricably linked to strategic risk. Strategic risk includes reputation risk, competition risk, and regulatory risk.Multiple types of risk management can be used to avoid losses from occurring as a result of these risks. The following paragraph will go over risk management in further detail.

\section{RISK MANAGEMENT:}

Risk management has a long history. Experience, intuition, and gut feeling have all been used to mitigate risk. Things began to alter as a result of the financial troubles caused by the dot-com boom and bust at the end of the previous century. As a result of the crisis, specific sets of laws for specific industries were created. Basel and the Solvency Directive were designed for the banking and insurance industries, respectively. Each of these sets comprises rules governing the amount of risk that businesses can take and the financial buffers they must have to stay afloat. In Chapter 2.5, we'll go over the topic of solvency in greater depth.

With these methodical approaches, With these systematic approaches in place, Williams, Bertsch, Dale, Warden, Smith, and Visser (2006, p68) proposed a new definition for risk management: "Risk management attempts to provide decision-makers with a systematic strategy to managing with risk and uncertainty."There are three forms of risk, according to Williams et al. (2006), which overlap the previously listed risk classifications. First, there are the hazards that businesses must manage. Regulatory bodies and/or governments are frequently responsible for this. This category also includes management quality and several environmental issues. Second, any firm dealing with money has the traditional hazards of internal and external theft and fraud. These dangers are distinct because they are not subject to external regulation. To manage this type of risk, businesses need specialized solutions. Finally, risk management models are used to manage hazards. The enterprise risk management (ERM) framework is an integrated approach to risk management.Finally, risk management models are used to manage hazards. An example of such a model is the integrated enterprise risk management (ERM) framework developed by the Committee of Sponsoring Organizations of the Treadway Commission (COSO) (2004).

Traditional risk management and enterprise risk management (ERM), which will be covered shortly, are the two basic approaches to risk management in a company.Risk management in the traditional sense and risk management in the context of an organization.

Risk categories are divided into so-called risk silos in traditional risk management (Liebenberg \& Hoyt, 2003). This means that different forms of risk are managed individually, such as market, credit, liquidity, and operational risk. The disadvantage of this strategy is that, because the risks are broken out, each one must be addressed separately, resulting in inefficiencies in risk management.Enterprise risk management offers a different approach to risk management than traditional risk management. In a portfolio, risks are pooled together, resulting in residual risk. This residual risk is less expensive to hedge and insure since it is smaller than the sum of all dangers. The current portfolio theory discusses the risk reduction of the portfolio. This concept suggests that different assets in a portfolio react in opposite ways to the same event, with the negative move. ment being canceled out or decreased by the positive movement's influence.

This lowers the portfolio's total risk The focus is another distinction between traditional risk management and enterprise risk management. Traditional risk management focuses mostly on financial concerns, but ERM combines strategic and operational risk with financial risk into a single risk management framework.Because 
traditional risk management did not generate effective outcomes, enterprise risk management (ERM) was created (Lam, 2000). To assist organizations in evaluating and improving their ERM, COSO (2004) created an ERM Integrated framework. ".

Enterprise risk management is used by an entity's board of directors, management, and other personnel to identify potential events that may affect the entity, manage risk within its risk appetite, and provide reasonable assurance that entity objectives will be met in strategy setting and across the enterprise..," according to COSO (COSO, 2004, p. 2).

ERM's fundamental goal is to assist management in dealing with uncertainties, as well as the risks and opportunities that come with them, in the process of producing value. The COSO ERM - Integrated Framework will be discussed in further depth in the following paragraph.

\section{COSO'S INTEGRATED PLATFORM FOR ENTERPRISE RISK MANAGEMENT.}

COSO had successfully adopted the Internal Control-Integrated Framework in 1992, before the launch of the ERM - integrated framework. COSO launched a project in 2001 to establish a framework for analyzing and enhancing ERM after noticing the need for a framework to effectively detect, assess, and manage risk. The framework was completed in 2004 in collaboration with PricewaterhouseCoopers.Management must create strategy and objectives to properly balance growth and return goals, as well as related risks, to maximize value. The following six ERM capabilities will assist management in meeting the firm's performance goals while avoiding resource loss.

When examining diverse strategic circumstances, management must examine the firm's readiness to accept risks to align risk appetite and strategy. Setting associated objectives and developing strategies to control related risks are both necessary.ERM will aid in the identification and selection of different risk responses such as risk avoidance, reduction, sharing, and acceptance, which will improve risk response decisions.

Firms acquire greater competence to identify probable occurrences and build reactions by applying ERM, which reduces operational surprises and losses.

Different elements of a company are exposed to risk. By permitting effective response to the linked implications of various risks, ERM aids in the identification and management of multiple and cross-enterprise risks. Management is better positioned to recognize and capitalize on opportunities by examining the complete range of possible events.

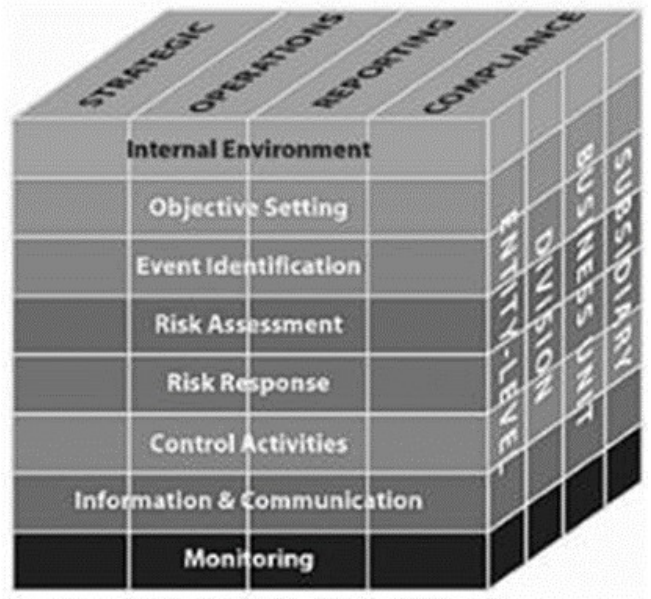

The three dimensions of the COSO ERM model are depicted in Figure 2.1. The achievement of objectives is the first dimension. The top of the cube displays the four categories in which targets will be met. The classification of objectives provides for a more focused approach.ERM is divided into different aspects. Reporting and compliance goals are within the entity's control, whereas strategic and operational goals are subject to external events that are not necessarily within the entity's control.The ERM's eight interconnected components make up the second dimension, which is depicted on the front of the cube. These elements are drawn from how management manages an organization and are integrated into the management process.

The units of the entity are displayed on the right side in the third dimension. The capacity to focus on the full of an entity's ERM, on all three dimensions, or by objectives category, component, entity unit, or any subset thereof is depicted by the three-dimensional portrayal of the ERM model (COSO, 2004).

THE ADVANTAGES OF RISK MANAGEMENT:

Risk management strategies include corporate insurance and hedging. Corporate insurance covers the financial 
implications of activities by company representatives, as well as malfunctioning products and faulty services, and it comes in a variety of forms. General liability insurance, for example, covers against claims involving workers, products, or services. Professional liability insurance, for example, protects against claims of malpractice, negligence, or errors from clients.'Directors and officers insurance,' for example, protects against charges of mismanagement. General liability insurance frequently excludes the second and third scenarios (Kumaraswamy, 2005).

Both of these strategies are costly, but when used as part of a firm's financing strategy, they have the potential to raise the firm's value (Liebenberg \& Hoyt, 2003). According to Mayers \& Smith (1982), corporation insurance has an impact on business value through influencing investment policy, contracting costs, and tax liabilities.

According to theory, corporation insurance helps to lower predicted bankruptcy costs, tax burdens, and regulatory scrutiny expenses. Several studies have backed up these views (Mayers \& Smith, 1990; Ashby \& Diacon, 1998; Hoyt \& Khang, 2000).

Corporation hedging, like corporate insurance, lowers predicted bankruptcy costs. This is accomplished by lowering the likelihood of financial trouble (Smith \& Stulz, 1985). Hedging reduces expected taxes and improves the firm's ability to take advantage of attractive investment opportunities, according to the hedging literature (see Smith \& Stulz, 1985; MacMinn, 1987; Campbell \& Kracaw, 1990; Bessembinder, 1991; Froot, Scharfstein \& Stein, 1993; Nance, Smith \& Smithson, 1993.

\section{FIND A HOLE:}

Insurance businesses have been subjected to additional regulations in recent decades. The Solvency II Directive has been in the works for some years and will take effect in 2016. The question now is whether risk management standards are sufficient to prevent problems from arising, as we witnessed during the last crisis. There is still no evidence that implementing Enterprise Risk Management (ERM) leads to improved results. As a result, more study is needed to investigate the link between ERM deployment and financial crisis performance.Dignity, truthfulness, justice, and responsibility, and freedom are the four main values at the foundation of education. All teaching is built on ethics, whether it's the teacher-student relationship, pluralism, or a teacher's relationship with their profession. Dignity entails respect for all people.The COSO-created ERM framework does include the components "reporting" and "compliance." When putting this into practice, keep in mind that.

\section{LINK FOR DEBATES:}

The researcher's review of the previous literature and studies on the topic of the research like Chris Daykin (2011), Micah Brame (2018), Donatien Hainaut (2020)have shown the importance of studying contemporary actuarial science and benefiting from it in limiting the negative and mixed results resulting from insurance companies through the mathematical methods used globally, including as mentioned by both and the importance of contemporary actuarial science in determining insurance risks in Australia

\section{METHODOLOGY:}

\section{STATEMENT OF LIMITATIONS:}

This study contains limitations in addition to contributions. First, the regression model built was flawed, providing no answers to the implications of ERM implementation level. As a result, correlations and t-tests produced all of the statistically significant results.Second, an ERM index was created due to data restrictions on ERM adoption in the sample firms. Some ERM implementation indicators were probably left out of the PCA. This may have resulted in certain organizations receiving a low score on ERM implementation when they fact had a high degree of ERM in place, and vice versa. Multiple ERMs are ideal.

WHAT YOUR RESEARCH WILL DO. This may have resulted in certain organizations receiving a low score on ERM implementation when they fact had a high degree of ERM in place, and vice versa. Multiple ERM implementation measurement methods would have been ideal, but this was not possible owing to scheduling constraints.

Finally, the sample size was only 39 firms, which is insufficient to draw generalizations about the entire insurance industry. This sample also included a mix of a subsidiary and parent companies. This combination resulted in the elimination of eight of the initial 48 firms, resulting in a reduction in the total number of enterprises. the instance Using subsidiary enterprises also made it impossible to calculate Tobin's Q, a widely used indicator of financial health.

\section{RECOMMENDATIONS:}

1.Companies in Australia carry out periodic actuarial studies to reduce the degree of insurance risk.

2- That some insurance companies bring in actuarial experts to examine the solvency of local insurance companies and link actuarial studies of foreign companies to local companies so that they can set the financial 
policies of insurance companies accurately.

3- Sending some employees to countries related to actuarial studies to be able to bring in the actuarial expertise and skills that work to monitor the insurance sector by reconsidering the actuarial studies conducted by local companies in European countries. that companies located within Australia disclose their actuarial studies so that local companies can deal with some of their monetary policies in collecting insurance premiums; In order not to expose domestic insurance companies to the risk of non-payment.

4. Coordination in the exchange of actuarial studies so that they can know where the insurance sector activity has reached compared to the fact that local companies establish a department specialized in actuarial studies in each company to expand the scope of insurance. Without resorting to conducting external studies for large sums of money, or attracting insurance experts to study the adequacy of financial coverage in creating a new insurance activity.

5- Conduct periodic actuarial studies to reduce the degree of insurance risks.

\section{REFERENCES:}

- Aebi, V., Sabato, G., \& Schmid, M. (2012). Risk management, corporate governance, and bank performance in the financial crisis. Journal of Banking \& Finance, 36(12), 3213-3226.

- $\quad$ Ai, J., \& Brockett, P. L. (2008). Enterprise Risk Management (ERM). Encyclopedia of Quantitative Risk Analysis and Assessment. Chichester: John Wiley \& Sons Ltd.

- Allen, L., \& Rai, A. (1996). Operational efficiency in banking: An international comparison. Journal of Banking \& Finance, 20(4), 655-672.

- $\quad$ Anderson, R. C., \&Reeb, D. M. (2003). Founding-family ownership and firm performance: evidence from the S\&P 500. The journal of finance, 58(3), 1301-1327.

- Ashby, S. G., \& Diacon, S. R. (1998). The Corporate Demand for Insurance: A Strategic Perspective, Geneva Papers on Risk and Insurance, 23, 34-51.

- Basle Committee on Banking Supervision. (2004). International convergence of capital measurement and capital standards: a revised framework. Basel: Bank for International Settlements.

- $\quad$ Baxter, R., Bedard, J. C., Hoitash, R., \&Yezegel, A. (2013). Enterprise risk management program quality: Determinants, value relevance, and the financial crisis. Contemporary Accounting Research, 30(4), 12641295.

- $\quad$ Bessembinder, H. (1991). Forward contracts and firm value: Investment incentive and contracting effects. Journal of Financial and quantitative Analysis,26(04), 519-532.

- $\quad$ Beasley, M. S., Clune, R., \& Hermanson, D. R. (2005). Enterprise risk management: An empirical analysis of factors associated with the extent of implementation. Journal of Accounting and Public Policy, 24(6), 521-531.

- Beasley, M., Pagach, D., \& Warr, R. (2008). Information conveyed in hiring announcements of senior executives overseeing enterprise-wide risk management processes. Journal of Accounting, Auditing \& Finance, 23(3), 311-332.

- Campbell, T. S., \& Kracaw, W. A. (1990). Corporate risk management and the incentive effects of debt. The journal of finance, 45(5), 1673-1686.

- Casualty Actuarial Society. Overview of Enterprise Risk Management. May 2003. Retrieved July 10th, 2013, from http://www.casact.org/area/erm/overview.pdf.

- $\quad$ Cerny, B. A., \& Kaiser, H. F. (1977). A study of a measure of sampling adequacy for factor- analytic correlation matrices. Multivariate Behavioral Research, 12(1), 43-47.

- $\quad$ Clarke, M., Seng, D., \& Whiting, R. H. (2011). Intellectual capital and firm performance in Australia. Journal of Intellectual Capital, 12(4), 505-530.

- Colquitt, L. L., Hoyt, R. E., \& Lee, R. B. (1999). Integrated risk management and the role of the risk manager. Risk Management and Insurance Review, 2(3), 43-61.

- Commission of Committee of Sponsoring Organizations of the Treadway. (2004). Enterprise risk management - An integrated framework. Executive summary

- Cumming, C. M., \&Hirtle, B. J. (2001). The challenges of risk management in diversified financial companies. Federal Reserve Bank of New York Economic Policy Review, 7(1), 1-17.

- Cummins, J. D., Lewis, C. M., \& Wei, R. (2006). The market value impact of operational loss events for US banks and insurers. Journal of Banking \& Finance, 30(10), 2605-2634.

- Cummins, J. D., \& Weiss, M. A. (2013). Analyzing firm performance in the insurance industry using frontier efficiency and productivity methods. In Handbook of insurance (p. 795-861). New York: Springer.

- Dogan, M. (2013). Does Firm Size Affect The Firm Profitability? Evidence from Turkey. Research Journal of Finance and Accounting, 4(4), 53-59.

- Eckles, D. L., Hoyt, R. E., \& Miller, S. M. (2014). The impact of enterprise risk management on the marginal cost of reducing risk: Evidence from the insurance industry. Journal of Banking \& Finance, 43, 
247-261

- Elango, B., Ma, Y. L., \& Pope, N. (2008). An investigation into the diversification- performance relationship in the US property-liability insurance industry. Journal of Risk and Insurance, 75(3), 567-591.

- $\quad$ Eling, M. \&Schmeiser, H. (2010). Insurance and the Credit Crisis: Impact and Ten Consequences for Risk Management and Supervision. The Geneva Papers, 35, 9-34.

- Ellul, A., \&Yerramilli, V. (2013). Stronger risk controls, lower risk: Evidence from US bank holding companies. The Journal of Finance, 68(5), 1757-1803.

- Erkens, D. H., Hung, M., \& Matos, P. (2012). Corporate governance in the 2007-2008 financial crisis: Evidence from financial institutions worldwide.Journal of Corporate Finance, 18(2), 389-411.

- $\quad$ Field, A. P. (2005). Discovering statistics using SPSS (2nd edition). Sage, London.

- $\quad$ Froot, K. A., Scharfstein, D. S., \& Stein, J. C. (1993). Risk managements coordinating corporate investment and financing policies. the Journal of Finance, 48(5), 1629-1658.

- Gordon, L. A., Loeb, M. P., \& Tseng, C. (2009). Enterprise risk management and firm performance: A contingency perspective. Journal of Accounting and Public Policy, 28(4), 301-327.

- $\quad$ Horcher, K. A. (2005). Essentials of Financial Risk Management? Hoboken, NJ: John Wiley \& Sons, Inc.

- Hoyt, R. E., \& Khang, H. (2000). On the Demand for Corporate Property Insurance, Journal of Risk and Insurance, 67(1), 91-107.

- Hoyt, R. E., \& Liebenberg, A. P. (2011). The value of enterprise risk management. Journal of Risk and Insurance, 78(4), 795-822.

- Jensen, M. C. (1986). Agency costs of free cash flow, corporate finance, and takeovers. The American economic review, 323-329.

- Kumaraswamy, S. (2005). Corporate Insurance: A Primer for Business Managers, CEOs and CFOs. New Delhi: Tata McGraw-Hill Education.

- $\quad$ Kleffner, A. E., Lee, R. B., \& McGannon, B. (2003). The effect of corporate governance on the use of enterprise risk management: Evidence from Canada. Risk Management and Insurance Review, 6(1), 53-73.

- $\quad$ Laeven, R. J. A. \&Perotti, E. C. (November 9, 2010). Optimal Capital Structure for Insurance Companies. Netspar Discussion Paper No. 11/2010-073. Downloaded on 18-01-2013, from: http://papers.ssrn.com/sol3/papers.cfm?abstract_id=1730231.

- $\quad$ Lam, J. C., \& Kawamoto, B. M. (1997). Emergence of the chief risk officer. Risk Management, 44(9), 3036.

- Lam, J. (2000). Enterprise-wide risk management and the role of the chief risk officer. white paper, ERisk.com, March, 25.

- $\quad$ Lam, J. (2001). CRO: Here to Stay. Risk management, 48(4), 16-24.

- $\quad$ Leach, J., \&Melicher, R. (2012). Entrepreneurial Finance. Mason: South-Western.

- $\quad$ Liebenberg, A. P., \& Hoyt, R. E. (2003). The determinants of enterprise risk management: Evidence from the appointment of chief risk officers. Risk Management and Insurance Review, 6(1), 37-52.

- MacMinn, R. D. (1987). Insurance and Corporate Risk Management, Journal of Risk and Insurance, 54(4), 658-677.

- $\quad$ Mayers, D., \& Smith, C. W. (1982). On the Corporate Demand for Insurance, Journal of Business, 55(2), 281-296.

- Mayers, D., \& Smith, C. W. (1990). On the Corporate Demand for Insurance: Evidence from the Reinsurance Market, Journal of Business, 63(1), 19-40.

- $\quad$ McNeil, A.J., Frey, R. \&Embrechts, P. (2005). Quantitative Risk Management: Concepts, Techniques and Tools. Princeton, NJ: Princeton University Press.

- McShane, M. K., Nair, A., \&Rustambekov, E. (2011). Does enterprise risk management increase firm value?. Journal of Accounting, Auditing \& Finance, 26(4), 641-658.

- $\quad$ Merton, R. C., \& Perold, A. (1993). Theory of risk capital in financial firms. Journal of Applied Corporate Finance, 6(3), 16-32.

- Meulbroek, L. K. (2002). A senior manager's guide to integrated risk management. Journal of Applied Corporate Finance, 14(4), 56-70.

- Mongiardino, A., \& Plath, C. (2010). Risk governance at large banks: Have any lessons been learned?. Journal of Risk Management in Financial Institutions, 3(2), 116-123.

- $\quad$ Myers, S.C. \& Read, J.A. Jr. (2001). Capital Allocation for Insurance Companies. The Journal of Risk and Insurance, 68 (4), 545-580.

- Nair, A., Rustambekov, E., McShane, M., \&Fainshmidt, S. (2013). Enterprise Risk Management as a Dynamic Capability: A test of its effectiveness during a crisis. Managerial and Decision Economics.

- Nance, D. R., Smith, C. W., \& Smithson, C. W. (1993). On the determinants of corporate hedging. The Journal of Finance, 48(1), 267-284.

- $\quad$ Pagach, D., \& Warr, R. (2010). The effects of enterprise risk management on firm performance. Retrieved 
May, 12, 2014, from http://ssrn.com/abstract=1155218

- Palia, D. (2001). The endogeneity of managerial compensation in firm valuation: A solution. Review of Financial Studies, 14(3), 735-764.

- $\quad$ Parinet, B., Lhote, A., \&Legube, B. (2004). Principal component analysis: an appropriate tool for water quality evaluation and management-application to a tropical lake system. Ecological Modelling, 178(3), 295-311.

- Quon, T. K., Zéghal, D., \&Maingot, M. (2012). Enterprise risk management and business performance during the financial and economic crises.

- $\quad$ Smith, C. W., \& Stulz, R. M. (1985). The determinants of firms‘ hedging policies. Journal of financial and quantitative analysis, 20(4), 391-405.

- $\quad$ Smithson, C., \& Simkins, B. J. (2005). Does risk management add value? A survey of the evidence. Journal of Applied Corporate Finance, 17(3), 8-17.

- Van Groningen, B. \& De Boer, C. (2010). Beschrijvendestatistiek: Het berekeneneninterpreteren van tabellenenstatistieken. Den Haag: Boom Lemma uitgevers.

- $\quad$ Williams, R., Bertsch, B., Dale, B., van der Wiele, T., van Iwaarden, J., Smith, M., \& Visser,

- $\quad$ R. (2006). Quality and risk management: what are the key issues? The TQM Magazine, 18(1), 67-86. 